FACTA UNIVERSITATIS

Series: Physical Education and Sport, Vol. 16, No 3, 2018, pp. 697 - 708

https://doi.org/10.22190/FUPES180404062L

Research article

\title{
ATTACKING PERFORMANCE PROFILE OF FOOTBALL TEAMS IN DIFFERENT NATIONAL LEAGUES ACCORDING TO UEFA RANKINGS FOR CLUB COMPETITIONS
}

\author{
UDC 796.332 \\ 796.093.1(4)
}

Bojan Leontijević, Aleksandar Janković, Lazar Tomić

Faculty of Sport and Physical Education, University of Belgrade, Belgrade, Serbia

\begin{abstract}
The aim of this study was to compare the attacking performance profiles of the football teams playing in national leagues of different rankings, defined on the basis of the Union of European Football Associations (UEFA) coefficient regarding club competitions. Applying the method of random sampling, one national league belonging to the first group4 participants in the Champions League and 3 teams participating in the Europa League (CLA+EL3; Germany), one belonging to the second group - CL3+EL3 (France), one belonging to the third group $(C L 2+E L 3$; Austria) and one from the fourth group $-C L 1+E L 3$ (Serbia) were selected. The analysis included all championship matches within the mentioned national competitions during the 2016/2017 season, which was a total of 1162 matches. The variables related to ball possession, passing game structure and efficacy and goal scoring attacks were monitored (19 variables in total). The results of this study have shown that there are significant differences in the organization of attacking games by the teams competing in the leagues of different rankings. It can be concluded that the players of the teams from the German and French leagues possess higher quality in a technical and tactical sense, and are trained to play extremely fast, with a high degree of success in ball control.
\end{abstract}

Key words: soccer, game analysis, UEFA ranking, attacking profile, possession game

\section{INTRODUCTION}

Sport represents a domain where various function and effects can be manifested (Savić, Randjelović, Stojanović, Stanković, \& Šiljak, 2017). Match analysis, in modern sports, is an essential way of collecting objective data about the quality of athletes' performance (Carling,

Received April 4, 2018 / Accepted December 28, 2018

Corresponding author: Bojan Leontijević

University of Belgrade, Faculty of Sport and Physical Education, Blagoja Parovića 156, 11000 Belgrade, Serbia

Phone: +381 $113531000 •$ E-mail: bojan.leontijevic@gmail.com 
Williams, \& Reilly, 2005). In addition, by watching opponents' matches, the qualities as well as the weaknesses in a team's play can be observed (Carling, Bloomfield, Nelsen, \& Reilly, 2008). According to its structure, football is a very complex sports game of changing dynamics, dominated by polystructural movements; therefore, it is difficult to predict how certain situations would be solved eventually in play. However, the subject of numerous studies was the analysis of some technical and tactical activities in order to determine the parameters which contribute to achieving successful results in football (Barreira, Vendite, \& Vendite, 2016; Castellano, Casamichana, \& Lago, 2012; Bekris, Gioldasis, Gissis, Komsis, \& Alipasali, 2014; Liu, Gomez, Lago-Peñas, \& Sampaio, 2015; Liu, Yi, Gimenez, Gomez, \& Lago-Peñas, 2015; Janković, Leontijević, \& Sofronijević, 2015; Leontijević, Janković, \& Tomić, 2015) and some similar games with ball (Vukosavljević, Kocić, Berić, \& Stojić, 2015; Kocić, Berić, \& Stevanović, 2016). Additionally, some studies aimed at identifying the modern trends characteristic of the most successful teams in modern football (Janković, Leontijević, \& Tomić, 2016; Leontijevic et al., 2017). Thus, studies have been directed towards determining certain laws and rules that are prerequisites for successful participation in various competitions.

Mackenzie \& Cushion (2013), in their review article, determined that teams' attacking performance has most often been analyzed in the studies conducted so far. By applying the method of comparative analysis (Sarmento et al., 2014), the attacking characteristics of the teams playing in the same competition (Leontijevic et al., 2017), but which differ in the final standing achieved (Lago-Ballesteros \& Lago-Peñas, 2010; Janković, Leontijević, Jelušić, Pašić, \& Micović, 2011) have been compared in a great number of studies. The authors also tried to identify the characteristics of attacking tactics that affected the match outcomes in relation to the dependent variables of "win", "tie" and "loss" (Castellano et al., 2012; LagoPeñas, Lago-Ballesteros, Dellal, \& Gómez, 2010). The results of the previous studies have shown that the total number and the number of accurate shots on goal, shots following counter attacks and shots realized within the 18-yard box were directly associated with positive outcomes (Castellano et al., 2012; Lago-Peñas et al., 2010; Liu et al., 2015a). In addition, the studies conducted by Janković et al. (2016) have shown that more accurate and efficient shots are characteristic of teams playing in competitions of higher quality. Increased ball possession, higher percentage of accurate passes, frequency of short passes, i.e. a tendency of organizing continuous attacks, also represent some of the parameters related to success in football (Bekris et al., 2014; Lago-Peñas et al., 2010; Liu et al., 2015a); however, Collet (2012) concluded that precise shots and passes are better predictors of the final outcome compared to ball possession.

The aim of the study was to qualitatively compare the attacking characteristics of the football teams participating in the competitions of different rankings, defined according to the Union of European Football Associations (UEFA) coefficient as well as to identify the tendencies in the attacking performances of the teams playing in the specified leagues. The results were expected to determine the modern trends characteristic of teams of different quality, as well as to determine the specificities related to the organization of attacking games of the teams belonging to the four national competitions differing in quality. Thus it would be observed whether the different tendencies separating the European teams in terms of quality are present in modern football and what they are. The obtained results may be used in planning the training units with the task of improving the organization of attacking games so that the teams competing in competitions of lower rankings could challenge the teams belonging to better national leagues in European competitions. 


\section{METHODS}

\section{Sample}

UEFA is an institution under whose patronage club and national competitions are organized in Europe. Based on the results achieved by European football clubs in European competitions, the coefficients for all UEFA member federations are determined at the end of each competition year (UEFA, n.d.). The assigned coefficients are defined by a number of teams, out of each national league, that will take part in the top-quality competition - the Champions League and the second-best competition - the Europa League in the following competition year. Accordingly, the first group included the national federations that provided 7 clubs for the European competitions, 4 - the Champions League and 3 - the Europa League (CL4+EL3); the second group included 6 clubs that play in European competitions, 3 - Champions League and 3 - Europa League (CL3+EL3); the third group included 5 clubs, 2 - Champions League and 3 Europa League (CL2+EL3); 4 clubs belong to the fourth group, 1 - Champions League and 3 Europa League (CL1+EL3). For the purposes of this study, by applying the method of random sampling, one national league was selected out of each group mentioned above, CL4+EL3 Germany, CL3+EL3 - France, CL2+EL3 - Austria and CL1+EL3 - Serbia, based on the coefficients at the end of the 2016/2017 season (UEFA's official website). All matches played in the national championships during the 2016/2017 season were analyzed, Germany - 306, France - 380, Austria - 180 and Serbia - 296, i.e. a total of 1162 matches were analyzed.

\section{Procedure and situational variable}

Data collection was carried out on the basis of the statistical analyses (reports) of the internet platform Instat scout, designed for professional athletes, coaches, players, scouts, managers etc. (instatsport.com). The Instat technology is used by all national associations whose championships were the subject of this research; therefore, a statistical report was made for each individual match. The same platform was used by Stanojević and Gyarmati (2016) to build performance profiles for players.

Nineteen variables were selected as predictor variables in the analysis and they were divided into three groups according to the available literature (Castellano et al., 2012; LagoPeñas, Lago-Ballesteros, \& Rey, 2011, Lago-Peñas, Lago-Ballesteros, Dellal, \& Gómez, 2010; Liu et al., 2013): (1) 6 variables related to goal scoring, (2) 7 variables related to ball possession, and (3) 6 variables related to passing and organizing. Operational definitions of these variables are as follows (Liu, Hopkins, Gómez, \& Molinuevo, 2013):

- Goals from positional attack (Goals-PA): Goal attack in open play or after set pieces (throw-in or free-kick). Positional attack in open play either lasts more than $30 \mathrm{sec}$ or the speed of moving to the target in ball possession is less than 2.6 meters/sec;

- Goals from counter-attack (Goals-CA): Open play goal attack after the opponent team loses the ball. A counter-attack lasts no longer than $30 \mathrm{~s}$. Speed of movement to the target in the counter-attack - no less than $2.6 \mathrm{~m} / \mathrm{s}$;

- Goals from set-pieces (Goals-SP): Goal attack which starts with a set piece (corner, throw-in or a free-kick) and its first or second action is a shot on goal or a cross into the box after which the goal is scored;

- Ball possession (min): Total time of ball possession;

- Ball possession quantity: Total number of arrivals in the possession of the ball; 
- Average time of ball possession: Average duration when a team takes over the ball from the opposing team without any clear interruption;

- Ball Possession < $5 \mathrm{~s}(\%)$ : Percentage of ball possessions when a team has the ball less than $5 \mathrm{sec}$;

- Ball Possession 5 - $15 \mathrm{~s}(\%)$ : Percentage of ball possessions when a team has the ball between 5 and 15 secs;

- Ball Possession 15 - $45 \mathrm{~s}(\%)$ : Percentage of ball possessions when a team has the ball between 15 and 45 secs;

- Ball Possession $45>\mathrm{s}(\%)$ : Percentage of ball possessions when a team has the ball more than $45 \mathrm{~s}$;

- Passes: Number of intentional played balls from one player to another;

- Accurate passes (\%): Successful passes as a proportion of total passes;

- Speed of accurate passes: Number of accurate passes per minute of ball possession;

- Short passes (\%): Percentage of successful passes shorter than $10 \mathrm{~m}$;

- Medium passes (\%): Percentage of successful passes between 10 and 30m;

- Long passes (\%): Percentage of successful passes longer than 30m;

- Duration of goal-scoring attack: The duration of the attack that ends with a goal;

- The average number of passes in goal-scoring attacks: Average number of passes conducted in each attack which ends with goal-scoring;

- Distance from goal scored: Average distance from goal of the player who scored the goal;

Variables in percent units (Ball Possession, Pass Accuracy) were analyzed as raw values. Other variables related to goal scoring, passing and organizing were analyzed as values adjusted to per $50 \%$ of ball possession of one's own team, which is,

$$
\mathrm{V}_{\text {ajstd }}-\left(\mathrm{V}_{\text {original }} / \mathrm{BP}_{\text {team }}\right) * 50 \%
$$

where $\mathrm{V}=$ value of the variable and BPteam $=$ Ball Possession of one's own team

\section{Statistical analysis}

Firstly, a descriptive analysis of the data was done (mean and standard deviation). Then, for identifying the differences of the performance profiles amongst the CL4+EL3, CL3+EL3, CL2+EL3 and CL1+EL3 league, the performance variables were tested by means of Kruskall-Wallis $\mathrm{H}$ and Chi-square tests with Bonferroni-Holm corrections for multiple comparisons because the assumptions of normality and homogeneity of variances were not satisfied. Statistical analysis was carried out using IBM SPSS Statistics v.20.0 for Windows (SPSS, Chicago, IL USA).

\section{RESULTS}

The results of this study have shown that there are some differences in technical and tactical performances between the teams that play in the national leagues of Germany, France, Austria and Serbia. The most significant differences may be observed in the variables related to ball possession and the structure and quality of the passing game, whereas the parameters indicating the structure and type of attacking games when scoring 
goals showed that there were no significant differences between the teams that participate in the leagues which differ in quality according to the UEFA coefficient.

Table 1 Differences in technical and tactical performances of the teams that play in league competitions of different quality (according to the UEFA coefficient)

\begin{tabular}{lccccccc}
\hline Variables & German & France & Austria & Serbia & $x^{2}$ & $d f$ & $p$ \\
\hline Related to goals scoring & & & & & & & \\
Goals - PA (\%) & 45.8 & 43.6 & 44.4 & 43.6 & 0.381 & 3 & 0.94 \\
Goals - CA (\%) & 22.6 & 24.7 & 24.1 & 23.8 & 0.519 & 3 & 0.915 \\
Goals - SP (\%) & 31.6 & 31.7 & 31.5 & 32.5 & 0.473 & 3 & 0.925 \\
Related to ball possession & & & & & & & \\
Ball possession (min.) & 26.39 & 27.11 & 25.39 & 26.46 & 2.875 & 3 & 0.411 \\
BP < 5 sec (\%) & $28.6^{* \#}$ & $28.2^{* \#}$ & 32.4 & 30.1 & 28.174 & 3 & 0.000 \\
BP 5 - 15 sec (\%) & $40.1^{* \#}$ & $39.4^{* \#}$ & 41.1 & 42.3 & 34.015 & 3 & 0.000 \\
BP 15 - 45 sec (\%) & 27.5 & 28.7 & 23.6 & 25.4 & 6.579 & 3 & 0.087 \\
BP 45 > sec (\%) & 4.2 & 3.8 & 2.8 & 2.4 & 7.503 & 3 & 0.057 \\
Related to passing & & & & & & & \\
Passes & 474.7 & 484.1 & 448.4 & 442.43 & 3.481 & 3 & 0.323 \\
Accurate passes (\%) & $81.1^{\#}$ & $82.7^{* \#}$ & 78.3 & 79 & 16.747 & 3 & 0.001 \\
SP - accurate (\%) & 80.1 & $83.1^{* \#+}$ & 78.3 & 80.1 & 18.951 & 3 & 0.000 \\
MP - accurate (\%) & 83.5 & $85^{* \#}$ & 81.4 & 81.7 & 12.982 & 3 & 0.005 \\
LP - accurate (\%) & $66.2^{*}$ & $66.2^{*}$ & 63.5 & 63.4 & 10.324 & 3 & 0.016 \\
\hline$\quad$ N) 1. PA - posin
\end{tabular}

Note 1. PA - positional attack; CA - counter-attack; SP - set-pieces; BP - ball possession;

SP - short passes; MP - medium passes; LP - long passes. $p<0.05$ (Bonferroni corrected);

Note 2. $x^{2}$ - Chi-squared statistics; df: Degrees of Freedom; Note 3. * - significant difference than Serbia; \# - significant difference than Austria; $\uparrow$ - significant difference than German

In regard to ball possession, when its duration is observed, it may be noticed that the teams playing in the German and French leagues had a significantly lower percentage of ball possession $<5 \mathrm{~s}$ and 5-15 $\mathrm{s}$ in relation to the teams competing in Austrian and Serbian leagues (German and France $<$ Serbia $(p<0.001)$; German and France $<$ Austria $(p<0.05)$; Table 1). Accuracy of passing the ball in attacking games was significantly greater in the play of the German league teams in relation to the Serbian league teams $(p<0.05)$, while the French teams were significantly more successful in this segment of the football game in relation to the teams belonging to Austrian and Serbian leagues $(\mathrm{p}<0.001)$. Extraordinary quality regarding the accuracy of the passing game was achieved by the teams of the French league at short distances (SP) in relation to any other league $(p<0.001)$. Passes realized over medium distances were also more accurate in the French league in relation to the leagues of Austria and Serbia $(p<0.001)$, whereas long range passes were more accurate in the leagues of Germany and France in relation to the Serbian league $(\mathrm{p}<0.05)$.

The structure of the attacking games resulting in goal scoring was similar across the examined leagues. Thus, there are no significant differences regarding the duration of attacking games, the number of passes and the distance from where shots on goal were realized by the teams from Germany, France, Austria and Serbia (Figure 1). However, it can be noticed that the average number of passes in goal scoring plays was slightly higher in the German league (6) and the league of France (5) in relation to the leagues of Austria and Serbia (4). In addition, the duration of attacking games was slightly longer, so that the 
attacks resulted in scoring goals lasted 19.1 seconds on average in the German league, while in the leagues of Austria and Serbia, they lasted 13.2 seconds on average (Figure 1).

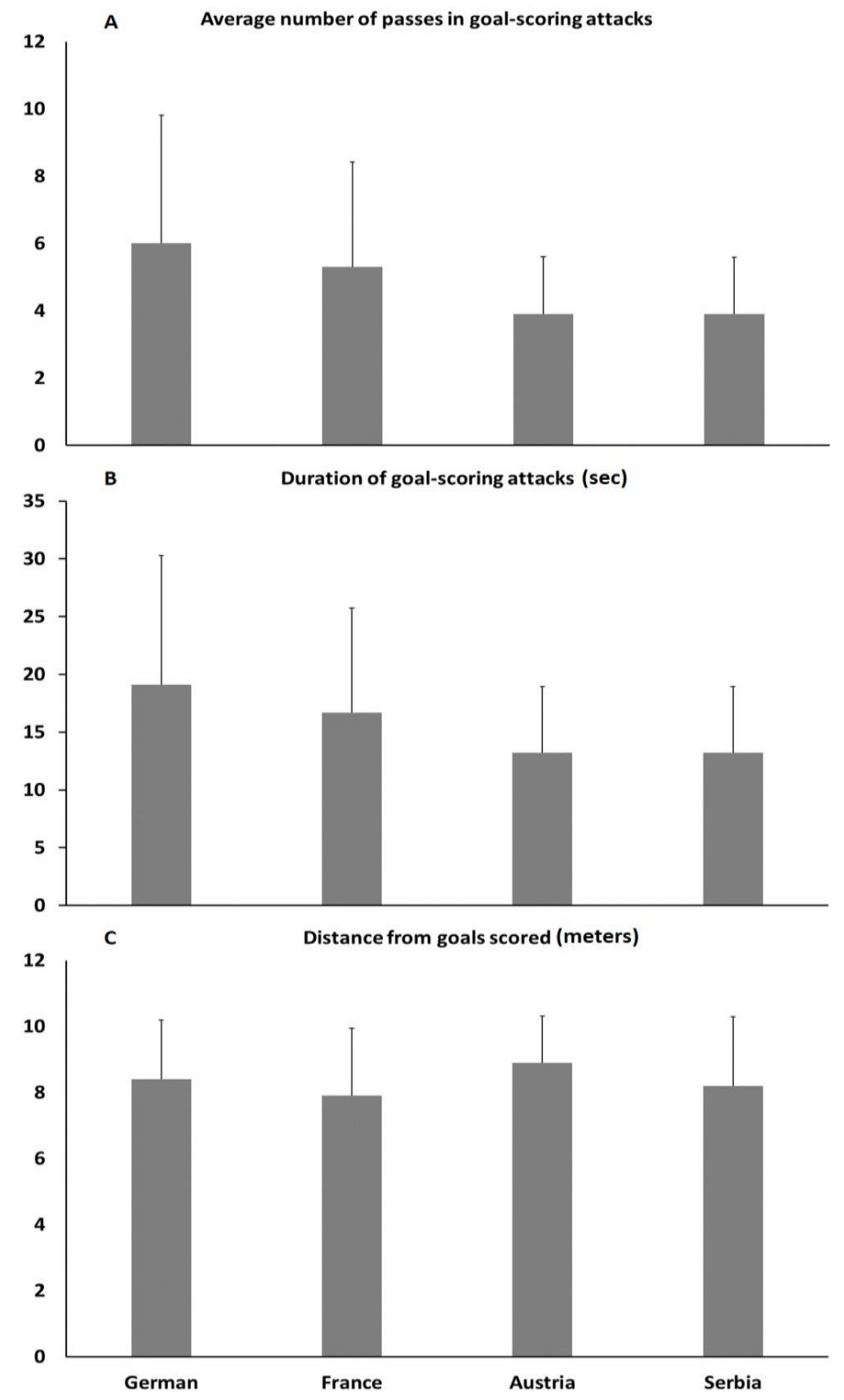

Fig. 1 Comparative analysis of the variables related to the attacks resulted in goal scoring (Mean and SD) in the national leagues of Germany, France, Austria and Serbia 

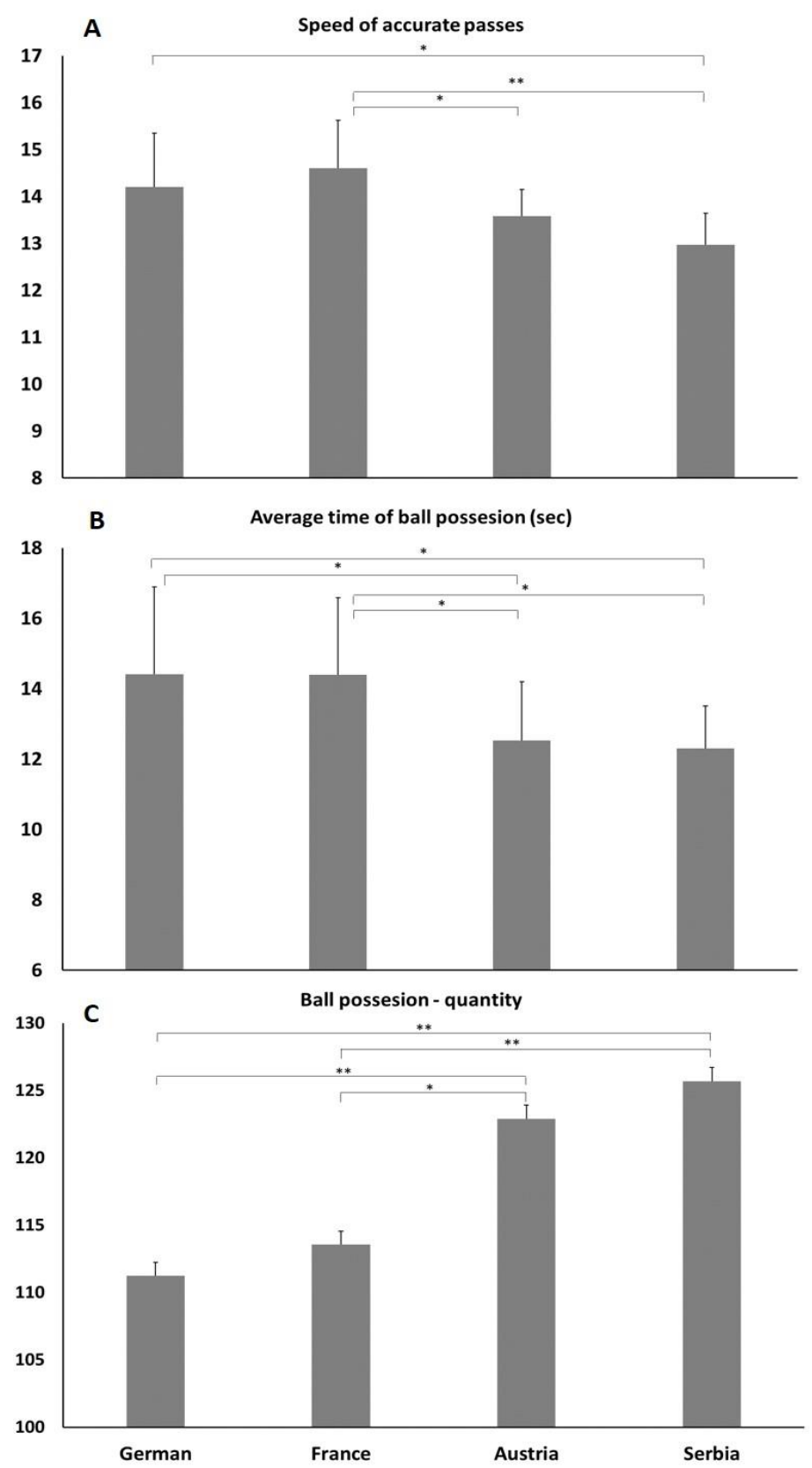

Fig. 2 Comparative analysis of the variables related to ball possession and passing game (Mean and SD) in the national leagues of Germany, France, Austria and Serbia; $* \mathrm{p}<0.05 ; * * \mathrm{p}<0.001$ (Bonferroni corrected) 
The number of winnings of the ball was significantly higher in the leagues of Serbia and Austria, especially in relation to the teams competing in the German league $(p<0.001)$, whose teams had the ball in their possession 111 times on average during one match, whereas in the Serbian league, one team took possession of the ball 126 times on average. Average time of keeping the ball in their possession was significantly greater in the leagues of Germany and Austria, but the speed of passing the ball between teammates when realizing attacks (Figure 2) was also higher. Average time of keeping the ball in their possession achieved by the Austrian and Serbian teams was $\approx 12$ seconds, while in the German and French leagues it was $\approx 14.5$ seconds. The speed of the passing game, as an indicator of the game style in a tactical sense, showed that the fastest games were realized in the French league, where the number of passes per ball possession in one minute was $\approx 15$, while it was $\approx 13$ in the Serbian league.

\section{DISCUSSION}

The aim of this study was to qualitatively compare the attacking characteristics of the football teams that play in the competitions of different rankings (according to the UEFA coefficient) as well as to identify the tendencies in the attacking tactics of the teams competing in these leagues. The results of the conducted study have shown that there are differences in regard to the organization and structure of attacking games between the examined national club competitions and that players also differ in respect to the quality of the manifestation of the ball control technique elements, which was confirmed by the study conducted by Janković et al. (2016) as well. The observed differences mostly referred to the teams competing in the leagues belonging to the first two groups (CL4+EL3 and CL3+EL3) in relation to the teams competing in the leagues belonging to the third and fourth group (CL2+EL3 and CL1+EL3). It may be concluded that the teams competing in the French and German leagues show similar tendencies when organizing their attacks. In some aspects, these tendencies differ from the attacking tendencies present in the leagues of Austria and Serbia, whereas, according to the findings of this study, there were no significant differences found between the competitive activities of the teams from Austria and Serbia in technical and tactical parameters, regarding the organization of their attacks.

It is difficult to predict a football game, but the previous studies that analyzed some technical and tactical activities managed to identify the characteristics which enhance the possibility of achieving success in football (Castellano et al., 2012; Lago-Peñas et al., 2010; Liu et al., 2015a; Liu et al., 2015b; Barreira et al., 2016; Bekris et al., 2014; Janković et al., 2015; Leontijević et al., 2015). However, this study is the first one to compare the teams included in four national competitions differing in quality and to examine them specifically in relation to the variables which were identified as the predictors of positive outcome in order to determine the differences and specificities in the organization of attacking games of the football teams playing in national competitions of different rankings.

According to the results obtained by Leontijević et al. (2015) and Janković et al. (2016), the teams whose players are trained to maintain their ball possession and organize continuous plays may achieve success in the competitive activity. The results of this study have shown that the teams belonging to the examined European leagues try to control the ball, i.e. they tend to maintain ball possession; therefore, the highest percentage of goals are 
scored immediately following the organization of continuous attacks (Table 1). Upon the organization of offensive stoppages, almost 1/3 of goals are scored in all the leagues, and the similar results were obtained by Taylor, James, \& Mellalieu (2005) and Armantas, Giannakos, \& Hatzimanouil (2007), thus, it may be concluded that practicing and improving this game segment is a very important factor in elite football. The lowest percentage of goals are realized following counter attacks. However, Yue, Broich, \& Mester (2014) concluded that counter attacks have an advantage over continuous attacks, due to greater efficacy. Their study did not examine the frequency of various types of attacks applied in matches, so that was the reason for a slightly higher percentage of efficacy during the organization of counter attacks, which was also emphasized in the study by Hughes \& Franks (2005).

The teams playing in the studied competitions do not differ in the overall ball possession per match $(\approx 27 \mathrm{~min})$, while, in the Champions League competition, the average ball possession is greater (Lago-Peñas et al., 2011; Leontijević et al., 2017). However, the analysis of the results has shown that significantly more changes in ball possession (graph 2) occurred in matches of the leagues classified into the third and fourth group (CL4+EL3 and CL3+EL3) as well as that the teams had more periods of ball possession lasting 5 and from 5 to 15 seconds in relation to the teams from France and Germany (Table 1). This finding can be interpreted as a result of these teams' inability to maintain ball possession for a longer period of time. A clear indicator of better technical and tactical preparedness of the players who play in first and second rank leagues has been also confirmed by the results showing that the average time of individual ball possession (Figure 2) realized by the teams from these leagues is significantly longer, as well as a slightly higher percentage of ball possession periods lasting 15-45 seconds and more than 45 seconds compared to the teams from Austria and Serbia (Table 1). Such findings may be explained by the higher quality of individual football players who compete in first and second rank leagues, in regard to technical and tactical preparedness when controlling and passing the ball. The quality regarding the field of technical and tactical preparedness of the players competing in the leagues of Germany and France can be described by the findings according to which the passing speed is significantly higher in these competitions (Figure 2) which further leads to faster advance of the ball during the organization of attacking games, which directly affects an increase in the game dynamics. Thus, it may be said that the game in the leagues of higher ranks is faster and more direct; in a tactical sense, the field is gained by passing the ball, the ball is not maintained in a player's possession for long, whereby the possibility of losing the ball through pressing by the opposition is reduced.

Ball possession in football depends on many factors and technical and tactical preparedness, where passing the ball between teammates is one of the most important preconditions; however, previous studies have shown that ball possession is not a factor which contributes to the results achieved in matches by the teams of equal or similar quality (Collet, 2012). There are no significant differences between the examined leagues in regard to a number of passes realized in matches (Table 2); however, there are significant differences in the percent of efficacy between the teams competing in the leagues of different groups, which represents another indicator of technical and tactical quality of the players of the teams included in these leagues. In previous studies it was concluded that the efficacy when passing the ball is an important precondition for players' successful performance in competitive activities and it represents a significant factor for achieving success in a match (Lago-Ballesteros \& LagoPeñas, 2010; Liu et al., 2015a) as well as that, in elite football, the presence of accurate 
passes is a better predictor of success compared to ball possession (Collet, 2012). Short passes represent a significant technical and tactical parameter in the competition of teams of similar quality (Liu et al., 2015a), and the results of this study have shown that teams from Germany and France had significantly greater efficacy when passing the ball over short, medium and long distances in relation to the teams from Serbia and Austria (Table 1). However, the teams competing in France realized a significantly greater number of accurate short passes than the teams from a league belonging to the first category (German league), which enables those teams to, due to the opponent's good defense organization, continually pass the ball on the ground between the teammates until a perfect opportunity for the final pass opens up, which represents an efficient attacking plan (Liu et al., 2015a).

By analyzing the structure of the attacks which resulted in goal scoring, the results have shown that efficient attacking games are most often realized with 4-6 passes (Figure 1), and according to Barreira et al. (2016), it is the most efficient way of enabling shots and scoring goals. The duration of efficient attacks is slightly increased per league rankings, which may be associated with the results related to ball possession and efficacy of the passing game (table 1). In addition, the distance from which shots on goal are realized is an important parameter in football that is also related to the final result (Bekris et al., 2014). In their study, Bekris, Mylonis, Sarakinos, Gissis, Gioldasis, \& Sotiropoulos (2013) presented the results indicating that the number of short distance shots was closely related to the final standing achieved by the teams competing in the Greek championship, and the results of this study have shown that, in the examined European league competitions, goals were most often scored from a distance of $\approx 8$ meters.

\section{CONCLUSION}

The conducted research has shown that there are differences in the organization of attacking activities, at individual, group as well as the team level. The ability to realize a high percentage of accurate passes over various distances, the ability to play under pressure, keeping the ball in possession over a longer period of time, faster ball distribution in organizing attacking games are characteristics of teams belonging to a higher rank of national competitions, which is defined by the UEFA coefficient regarding club competitions. It can be concluded that the players of the teams from the German and French leagues possess higher quality in a technical and tactical sense, and are trained to play extremely fast, with a high degree of success in ball control. The results of this study have pointed out the significance of football players' technical and tactical preparedness that should definitely be given special attention in young players' development in order to enable them to perform successfully in elite football competitions. Additionally, the collective attacking tactic is an area accompanying the process of football player's formation, making the quality of an individual serve as a function of achieving results.

\section{LIMITATIONS}

There are several limitations in the current research that should be considered in future studies. Firstly, the systems of competition in the examined European leagues are similar, but not the same and that may affect the result and performance of the teams and players. 
Secondly, the situational variables (strength of team, game location) are of great importance in football match performance analysis, as indicated by previous research (Mackenzie \& Cushion, 2013). Further modelling can be performed incorporating variables of quality of observed teams from different competitions (e.g. team rank at the end of the season).

\section{REFERENCES}

Armatas, V., Giannakos, A., \& Hatzimanouil, D. (2007). Record and evaluation of set-plays in European football championship in Portugal 2004. Sport \& Physical Education, 5(2), 302-307.

Barreira, J., Vendite, C., \& Vendite, L.L. (2016). Analysis of shots and passing sequence of a soccer team and its opponents during 2014 Brazilian championship. International Journal of Sports Science, 6(4), 163-167.

Bekris, E., Gioldasis, A., Gissis, I., Komsis, S., \& Alipasali, F. (2014). Winners and losers in top level soccer. How do they differ? Journal of Physical Education and Sport, 14(3), 398-405.

Bekris, E., Mylonis, E., Sarakinos, A., Gissis, I., Gioldasis, A., \& Sotiropoulos, A. (2013). Offense and defense statistical indicators that determine the Greek Superleague teams placement on the table 2011-12. Journal of Physical Education and Sport, 13(3), 338-347.

Carling, C., Williams, A.M., \& Reilly, T. (2005). Handbook of soccer match analysis. London: Routledge.

Carling, C., Bloomfield, J., Nelsen, L., \& Reilly, T. (2008). The role of motion analysis in elite soccer. Sports Medicine, 38(10), 839-862.

Castellano, J., Casamichana, D., \& Lago, C. (2012). The use of match statistics that discriminate between successful and unsuccessful soccer teams. Journal of Human Kinetics, 31(1), 139-147.

Collet, C. (2012). The possession game? A comparative analysis of ball retention and team success in European and international football, 2007-2010. Journal of Sports Sciences, 31(2), 123-136.

Hughes, M., \& Franks, I. (2005). Analysis of passing sequences, shots and goals in soccer. Journal of Sport Sciences, 23(5), 509-514.

Janković, A., Leontijević, B., \& Sofronijević, F. (2015). Comparative analysis of football technical competitive activity between UEFA Champions League and Serbian Super League. Physical Culture, 69(2), 129-137.

Janković, A., Leontijević, B., \& Tomić, L. (2016). Attacks of the soccer teams participating in the Champions League and the Serbian Super League. Physical Culture, 70(1), 80-87.

Janković, A., Leontijević, B., Jelušić, V., Pašić, M., \& Micović, B. (2011). Influence of tactics efficiency on results in Serbian soccer Super League in season 2009/2010. Journal of Physical Education and Sport, 11(1), 32-41.

Kocić, M., Berić, D., \& Stevanović, M. (2016). Efficiency of ball manipulation in basketball players. Facta Universitatis Series Physical Education and Sport, 14(1), 23-30.

Lago-Ballesteros, J., \& Lago-Peñas, C. (2010). Performance in team sports: Identifying the keys to success in soccer. Journal of Human Kinetics, 25(1), 85-91.

Lago-Peñas, C., Lago-Ballesteros, J., \& Rey, E. (2011). Differences in performance indicators between winning and losing teams in the UEFA Champions League. Journal of Human Kinetics, 27, 135-146.

Lago-Peñas, C., Lago-Ballesteros, J., Dellal, A., \& Gómez, M. (2010). Game-related statistics that discriminated winning, drawing and losing teams from the Spanish soccer league. Journal of Sports Science and Medicine, 9(2), 288-293.

Leontijević, B., Janković, A., \& Ćosić, N. (2015). Comparative analysis of tactical manifestation of Partizan players to matches in European competitions and the Super League Serbia. In Serbian. In G. Kasum, \& M. Mudrić (Eds.). International Scientific Conference "The effects of physical activity application to anthropological status of children, youth and adults", (pp. 443-450). Belgrade: Faculty of Sport and Physical Education, University of Belgrade

Leontijević, B., Janković, A., \& Tomić, L. (2017). Tactics of attack of football teams in the Champions League knockout phase in seasons of 2015/2016 and 2016/2017. Physical culture, 71(2), 137-144.

Liu, H., Hopkins, W., Gómez, M.A., \& Molinuevo, J.S. (2013). Inter-operator reliability of live football match statistics from OPTA Sportsdata. International Journal of Performance Analysis in Sport, 13, 803-821.

Liu, H., Gomez, M.Á., Lago-Peñas, C., \& Sampaio, J. (2015a). Match statistics related to winning in the group stage of 2014 Brazil FIFA World Cup. Journal of Sports Sciences, 33(12), 1205-1213.

Liu, H., Yi, Q., Gimenez, J.V., Gomez, M.A., \& Lago-Peñas, C. (2015b). Performance profiles of football teams in the UEFA Champions League considering situational efficiency. International Journal of Performance Analysis in Sport, 15, 371-390.

Mackenzie, R., \& Cushion, C. (2013). Performance analysis in football: A critical review and implications for 
future research. Journal of Sports Sciences, 31(6), 639-676.

Sarmento, H., Marcelino, R., Anguera, M.T., CampaniÇo, J., Matos, N., \& Leitao, J.C. (2014). Match analysis in football: a systematic review. Journal of Sports Sciences, 32(20), 1831-1843.

Savić, Z., Randjelović, N., Stojanović, N., Stanković, V., \& Šiljak, V. (2017). The sports industry and achieving top sports results. Facta Universitatis Series Physical Education and Sport, 15(3), 513-522.

Stanojević, R., \& Gyarmati, L. (2016). Towards data-driven football player assessment. IEEE International Conference on Data Mining Workhops, (pp. 167-172). Spain: Barcelona. Retrieved on September 16, 2017 from the World Wide Web: http://ds.qcri.org/publications/2016-stanojevic-icdmw.pdf

Taylor, J.B., James, N. \& Mellalieu, S.D. (2005). Notational analysis of corner kicks in English Premier League soccer. In T. Reilly, J. Cabri, \& D. Araujo (Eds.), Science and Football V: the proceedings of the Fifth World Congress on Science and Football, (pp. 229-234). London: Routledge

Vukosavljević, J., Kocić, M., Berić, D., \& Stojić, M. (2015). The situation success in the handball: Review. Facta Universitatis Series Physical Education and Sport, 13(1), 97-105.

Union of European Football Associations -UEFA (n.d.). www.uefa.com (online). Retrieved on September 20, 2017 from the World Wide Web: URL: https://www.uefa.com/memberassociations/uefarankings/country/ Yue, Z., Broich, H., \& Mester, J. (2014). Statistical analysis for the soccer matches of the First Bundesliga. International Journal of Sport Science \& Coaching, 9(3), 553-560.

\section{NAPADAČKE KARAKTERISTIKE FUDBALSKIH TIMOVA IZ RAZLIČITIH NACIONALNIH LIGA PREMA UEFA RANGIRANJU ZA KLUPSKA TAKMIČENJA}

Cilj ovog istraživanja bio je da se uporede ofanzivne karakteristike igre fudbalskih timova koji nastupaju u nacionalnim takmičenjima različitog ranga, definisanog na osnovu UEFA koeficijenta za klupska takmičenja. Metodom slučajnog uzorka, odabrana je po jedna nacionalna liga iz prve grupe - 4 učesnika u Ligi Šampiona i 3 u Ligi Evrope (CL4+EL3; Nemačka), druge grupe - CL3+EL3 (Francuska), treće grupe - CL2+EL3 (Austrija) i četvrte grupe - CL1+EL3 (Srbija). Analizom su obuhvaćene sve prvenstvene utakmice u pomenutim nacionalnim takmičenjima u sezoni 2016/2017, ukupno 1162 utakmice. Praćene su varijable povezane sa posedom lopte, strukturom i efikasnošću u pas igri i napadima koji su završeni golom (ukupno 19 varijabli). Rezultati ovog istraživanja pokazali su da postoje značajne razlike u organizaciji napadačkih akcija timova koji nastupaju u ligama različitog ranga. Timovi iz prvog $i$ drugog ranga kada dođu u posed lopte značajno duže uspeju da je zadrže ( $p<0.05$ ), dok timovi iz trećeg $i$ četvrtog ranga više igraju u tranziciji na šta ukazuje veći broj poseda lopte ispod 5 i 15 sekundi $(p<0.001)$. Viši rang takmičenja odlikuje $i$ značajno veća brzina dodavanja lopte $(p<0.05)$ ali $i$ preciznost, posebno dodavanja na kraćim i srednjim distancama $(p<0.001)$. Struktura napada koji se završavaju golom ne razlikuje se značajno u sva četiri ranga takmičenja. Može se zaključiti da igrači u timovima koji nastupaju u Nemačkoj i Francuskoj ligi poseduju veći kvalitet u tehničkom i taktičkom smislu, i utrenirani su da igraju veoma brzo, uz veliki stepen uspešnosti u kontroli lopte.

Ključne reči: fudbal, analiza utakmice, UEFA rangiranje, napadački profil, posed igra 